og boken har et høyt vitenskapelig nivå. Den er i tillegg oversiktlig og aktuell (referanser til og med 2009). Det er noe overlapping i innhold mellom kapitlene, noe som er vanlig når det er mange ulike forfattere. Illustrasjonene er stort sett gode, med unntak av pasientillustrasjonene, som til dels er av dårlig kvalitet. Dette trekker helhetsinntrykket litt ned, men redaktørene lykkes svært godt med sin hensikt. Jeg anbefaler boken til alle som ønsker å fordype seg $i$ andrologifaget.

\section{Johan Svartberg}

Endokrinologisk seksjon

Medisinsk klinikk

Universitetssykehuset Nord-Norge

\section{Anestesifaget oppsummert}

Catherine Spoors, Kevin Kiff, red Training in anaesthesia

the essential curriculum. $621 \mathrm{~s}$, tab, ill. Oxford: Oxford University Press, 2010. Pris GBP 50 ISBN 978-0-19-922726-6

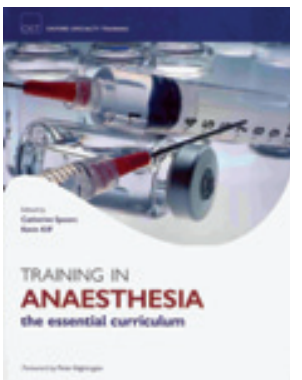

Undertittelen er på mange måter en god beskrivelse av denne boken. Den vil være en omfattende og god lærebok for nybegynneren, og den er avansert nok til å utgjøre en god oppsummering

også for den mer erfarne anestesilegen.

Oppbygningen er meget systematisk, og til tross for at boken er innholdsrik er den derfor enkel og forståelig å finne frem i. De 25 kapitlene dekker hovedområdene innenfor faget, og hvert kapittel er inndelt i emner som passende kan dekkes på to sider. Disse emnesidene er igjen arrangert slik at når boken ligger oppslått, er teksten typisk på venstre side og illustrasjonene på høyre side, noe som er oversiktlig og bra. Det er rikelig med illustrasjoner og tabeller, hvilket gjør det til dels teoritunge stoffet lettere tilgjengelig.

Innledningsvis er det fem generelle kapitler om gjennomføring av anestesi. Deretter følger hoveddelen, som utgjør en gjennomgang av organsystemene med hovedvekt på anatomiske og fysiologiske/ patofysiologiske forhold av særlig betydning for anestesien. Etter dette, mot slutten, er det egne kapitler om anestesi til barn, eldre og gravide. Deretter følger to kapitler om intensivmedisin og traumatologi, et kapittel om statistikk for anestesileger og til slutt en gjennomgang av anestesiologiske komplikasjoner.

Den største svakheten, for norske anestesiologer, er nok at forfatterne i all hovedsak setter søkelyset på anestesien. De tre gjenværende søylene, intensivmedisin, akuttmedisin og smertemedisin, er ikke dekket med tilnærmelsesvis samme detaljeringsgrad. Norske anestesiologer vil derfor ha behov for andre bøker innenfor disse delene av faget. Men altså, i sum, synes jeg det er en meget god bok som mange vil kunne ha nytte av; som første lærebok, til repetisjon eller som oppslagsverk.

En liten note til slutt: Forfatterne er til tider ganske detaljert i sine beskrivelser av metoder, forslag til utredninger, håndtering av komplikasjoner etc. Etter en gangs gjennomlesning fant jeg intet som åpenbart skiller seg fra hvordan ting håndteres i Norge, men det er like åpenbart at forskjeller vil finnes; de finner man jo også mellom sykehus i Norge. Om dette detaljnivået er en styrke eller svakhet, overlater jeg til leseren å vurdere; det vil blant annet avhenge av lokale forhold.

\section{Per Meinich}

Anestesiavdelingen

Akershus universitetssykehus

\section{Grundig om dødfødsler}

Fabio Facchinetti, Gustaaf A. Dekker,

Dante Baronciani et al, red.

\section{Stillbirth}

Understanding and management. 136 s, tab, ill. London: Informa Healthcare, 2010.

Pris GBP 125

ISBN 978-0-4154-7390-3

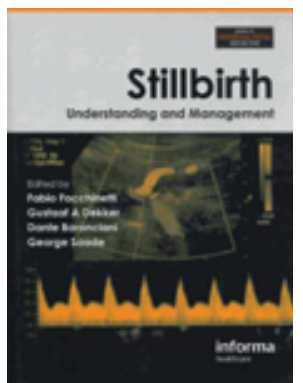

Denne boken inngår $i$ en etablert serie innen maternell og føtal medisin som utgis i samarbeid med tidsskriftet Journal of Maternal-Fetal and Neonatal Medicine.

Dette er en omfattende gjennomgang av emnet dødfødsler, både når det gjelder dokumentert kunnskap og klinisk håndtering. Den vil være svært nyttig for klinikere og forskere innen obstetrikk, neonatologi og patologi. Det mest besnærende er den parallelle presentasjonen av emnene slik de kan oppleves i så vel industraliserte land som i utviklingsland. Det gjør den ekstra verdifull for alle som jobber med internasjonal helse.

Det er i alt 24 bidragsytere og fire redaktører. De 13 kapitlene er gruppert i fire seksjoner: Bakgrunn, Klinikk, Årsaksforståelse og Håndtering. Det første kapitlet, Definition and epidemiology of stillbirth, er spesielt grundig og detaljert, men krever at leseren er konsentrert. Det er helt avgjø- rende siden hensikten er å introdusere sentrale begreper rundt dødfødslenes epidemiologi. Tallmaterialet gir en god forståelse av hvordan definisjoner, datainnsamling og statistikk påvirker kunnskap og styrer forebyggende tiltak.

I de følgende kapitlene belyser forfatterne dødfødsel i forhold til livsstilsrelaterte risikofaktorer, maternelle sykdommer, obstetriske forhold, prediksjon og forebygging. Det blir gjort rede for problemet med utgangspunkt i klinisk diagnostikk og undersøkelse, supplert med patologiske undersøkelser. Bokens betydning ser man også ved de grundige og gode kapitlene om sykehusets håndtering, rådgivning og oppfølging av par som opplever dødfødsel. Deretter følger kapittel om perinatal klinisk «audit» og klassifisering av dødfødte. På slutten er det en praktisk veiledning i håndtering av dødfødsel.

Den doble vinklingen mot i- og u-land som går som en rød tråd gjennom hele boken, gjør den fascinerende og tiltalende. Kapitlene kan leses separat, og det er i liten grad overlapp mellom dem. I den grad det forekommer, belyser man problemstillingen med stadig ny informasjon. Det er mye faktaopplysninger til å være rundt 130 sider. Samtidig trekker forfatterne klare konklusjoner som fester seg som ny kunnskap. Det gjelder f.eks. at i utviklingsland vil man ikke kunne forvente at en generell forbedring $i$ helse og omsorg vil påvirke forekomsten av dødfødsler. Derimot vil spesifikke tiltak som forebygging av infeksjoner, identifisering av preeklampsi og bedre fødsels- og barselfasiliteter gi gevinst. Viten om at $30-50 \%$ av fosterdød i utviklingsland skjer under fødselen gjør et sterkt inntrykk på en norsk obstetriker.

En rekke tilstander behandler man grundig og detaljert, og samtidig får leseren tydelig tak i den underliggende erkjennelsen av at intrauterin veksthemning er den største enkeltfaktoren som er forbundet med fosterdød (43\%). Man understreker betydningen og nødvendigheten av grundige patologiske undersøkelser, og at dette inkluderer placenta, fosterhinnene og navlesnoren. Andre gode momenter er når man påpeker forskjellen mellom risikofaktorer og kausale årsaker. Dette utdyper forfatterne spesielt godt $\mathrm{i}$ forhold til håndteringen av paret som har mistet sitt kommende barn.

Det er rikelig med figurer som, tross noen skjønnhetsfeil, supplerer og utfyller teksten. Hvert kapittel har en rekke referanser som letter lesningen. Det er inspirerende å få tilført denne omfattende faktakunnskapen. Uansett hvor viktig temaet er, har det lett for å bli underkjent. Spennet i emnene og presentasjonen gjør boken til en tankevekker.

Jeg synes at det følgende sitatet egner seg som avslutning: «The ultimate goal in studying stillbirth epidemiology is prevention. The vast majority of stillbirths are not 
only preventable, but simple inexpensive interventions could lead to an increase in births of healthy infants with greater life expectancy.»

Marit P. Martinussen

Kvinneklinikken

St. Olavs hospital

\section{Hendig om hudsykdom hos barn}

Sue Lewis-Jones, red.

Paediatric dermatology

616 s, tab, ill. Oxford: Oxford University Press, 2010. Pris GBP 45

ISBN 978-0-19-920838-8

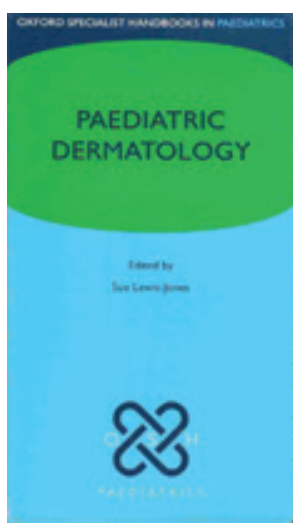

Pediatric Derma-

tology inngår

$i$ en serie med

medisinske hånd-

bøker, Oxford Spe-

cialist Handbooks.

I denne serien

foreligger nå en ny

bok, denne gangen

om hudsykdom-

mer hos barn og

ungdom.

Boken er dispo-

nert etter presentasjoner av hudfor-

andringene, og ikke i sykdomsgrupper. Fire av hovedseksjonene omhandler distribusjon av hudforandringene, type utslett (papu-

lære, pustuløse, urtikarielle etc.), overflateforandringer (blemmer, tumorer, ulcerasjoner etc.) og fargeendringer. I tillegg er det en innledende seksjon om generelle dermatologiske prinsipper og en seksjon om hudforandringer hos nyfødte.

Denne litt originale oppdelingen er bokens styrke. Hver enkelt tilstand blir omtalt i forskjellige kapitler, men indeksen og kryssreferansene fortløpende i teksten giør at det er forholdsvis lett å finne frem til stedet hvor den enkelte sykdommen er grundigst omtalt. Man skiller mellom vanlige og sjeldne tilstander, og det er oversiktlige algoritmer og lister med differensialdiagnoser. Formgivningen er tiltalende med fin veksling mellom fotografier, tabeller, tekst og faktabokser. Ved noen sykdommer gjør forfatterne dypdykk i genetiske eller molekylærbiologiske mekanismer, men den praktiske, kliniske tilnærmingen dominerer.

Sjeldne tilstander er kortfattet omtalt. Man bør konsultere andre kilder dersom det er behov for mer kunnskap, f.eks. tobindsverket av Bolognia og medarbeidere, som mange mener er dagens standardverk innen dermatologi (1). En alternativ håndbok er Color Atlas \& Synopsis of Pediatric Dermatology, som gjennomgående har høyere kvalitet på kliniske fotografier, et litt større format og med en mer tradisjonell disposisjon (2).

Boken har et hendig lommeformat og er trykket på tynt, matt papir med god kvalitet på bildene. Den har få mangler, og jeg kan anbefale den til leger som ønsker en håndbok om hudsykdommer hos barn og ungdom. Leseren bør ha noe forhåndskunnskap i dermatologi for lett å kunne anvende den. De mange tabellene og sjeldne diagnosene kan kanskje virke overveldende på en novise. Erfarne leger vil kunne ha god nytte av den, også som en rask oppfriskning.

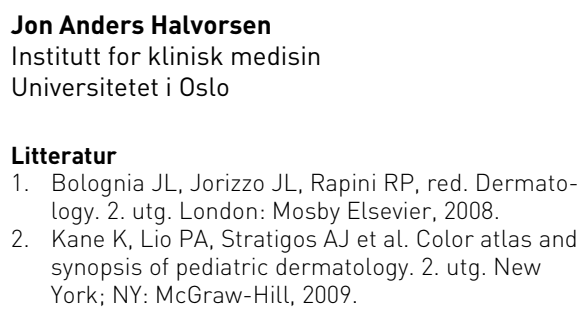

\section{Tankevekkende} om biobanker

Kris Dierichx, Pascal Borry, red.

New challenges for biobanks: ethics,

law and governance

277 s, ill. Mortsel: Intersentia Publishing, 2009. Pris EUR 62

ISBN 978-90-5095-974-2

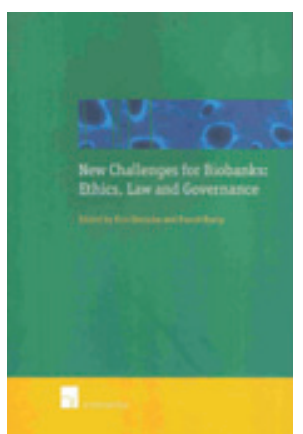

Biobanker er systematiske samlinger av humant biologisk materiale som blod og vev, innsamlet i forbindelse med diagnostikk, behandling, forskning eller rettslige unders $\varnothing-$ kelser. Biobanker, både arkivmate-

rialet og nye samlinger, er av uvurderlig betydning for medisinsk behandling og forskning, ikke minst i lys av utviklingen innen genomikk og informasjonsteknologi. Bruk av biologisk materiale medfører også en rekke etiske og rettslige dilemmaer som denne boken tar opp. Målgruppen angis å være sentrale politikere, lovgivere og fagfolk med ansvar for biobanker.

Dette er en samling artikler presentert på en internasjonal konferanse $\mathrm{i}$ Leuven i Belgia i 2009. Boken er inndelt i 19 kapitler med forskjellige forfattere, og forfatterne belyser en rekke temaer innen biobankvirksomhet, som informert samtykke, personvern, medbestemmelsesrett, kommersialisering, rettsmedisin, forskjeller innen europeisk lovregulering og kulturelle perspektiver. Kapitlet om kommersialise- ring er skrevet av forfattere fra Norges teknisk-naturvitenskapelige universitet. Hvert kapittel avsluttes med utfyllende referanser og fotnoter. Bakerst er det en liste over bidragsyterne med et kort sammendrag av nåværende funksjoner og interessefelt.

Biobanker er i Norge lovregulert hovedsakelig gjennom behandlingsbiobankloven, som regulerer diagnostikk- og behandlingsbiobanker, og helseforskningsloven, som regulerer forskningsbiobanker. Balansen mellom nødvendig ivaretakelse av personvern og unødvendig byråkratisering og lovregulering innen medisinsk forskning er et tema som stadig debatteres. Forfatterne gir en rekke viktige bidrag til denne diskusjonen. Hvordan skal f.eks. forskeren ivareta informasjonsplikten overfor donoren av biobankmaterialet? Hva er tilstrekkelig informasjon? Hvor bredt kan et samtykke være? Aktualiteten illustreres ved at Helseog omsorgsdepartementet i mars 2010 utga en omfattende veileder som vedlegg til helseforskningsloven, hvor man spesielt kommenterer informasjonsplikten og samtykke.

I kapitlet om kommersialisering av biobanker er erfaringer fra HUNT Biosciences AS i Nord-Trøndelag sammenliknet med UK Biobank og deCODE genetics. Dette er høyst relevant, ikke minst i lys av at Forskningsrådet gjennom to rapporter, Gode biobanker - bedre helse (1) og Potensial for kommersiell utnyttelse av humane biobanker (2), slår fast at kommersialisering er nødvendig for å optimalisere helsegevinster basert på forskning med biobankmateriale.

Rettsmedisinske biobanker er omtalt i flere kapitler. De fleste EU-land og USA har rettsmedisinske DNA-banker som inneholder DNA fra åstedsundersøkelser og DNA fra dømte, enkelte også DNA-prøver fra mistenkte. Dette har konsekvenser for individers rettsvern og personvern, og forholdet mellom frihet på den ene siden og sikkerhet på den andre siden problematiseres. Forfatterne klargjør forskjellen mellom det å oppbevare kun DNA-profiler, som bygger på ikke-kodende områder, og DNA-prøver som inneholder hele genomet.

Avslutningsvis er det en beskrivelse av drivkreftene bak store EU-baserte biobankprosjekter som BBMRI (Biobanking and Biomolecular Resources Research Infrastructure). Det vitenskaplige forskningsfokuset på systembiologien, hvor årsaksforståelsen av sykdom krever store multinasjonale biobanker, fordrer at vi lykkes med en europeisk harmonisering og standardisering av de humane biobankene på tvers av landegrensene.

Jeg anbefaler boken for lovgivere og andre med interesse og forvaltningsansvar for biobanker.

\section{Wenche Reed}

Stab forskning og utvikling

Oslo universitetssykehus, Ullevål 